\title{
BEYOND THE GAME: ANALYZING THE USEFULNESS OF GAMES TO PROMOTE LIFE SKILLS DEVELOPMENT
}

\author{
Mauro Henrique André \\ Illinois State University, Estados Unidos \\ James Lloyd Mandigo \\ Brock University, Canadá
}

\begin{abstract}
The current paper provides a reflection about games' 'power' to promote both 'good' and 'bad' learning. The study is organized in three sections. First, the complexity of games' nature is briefly introduced within diverse perspectives in order to provide an understanding why games are highly empowered. Second, an analysis of historical events and academic references show how games have been used to promote both good and bad events. Finally, two life experiences are presented in order to illustrate how games can provide opposite outcomes regardless of cultural differences. Thus, within a provocative reflexive, physical educators are encouraged to think what can be taught on their daily lesson that is "beyond" the learning of the game itself.
\end{abstract}

Keywords: Game Theory. Physical Education and Training. Community Development.

$\mathrm{I}$ n Nelson Mandela's (UNITED NATIONS, 2005, p. 9) speech to the International Year of Sport and Physical Education, he claimed that "sport has the power to change the world, the power to inspire, the power to unite people in a way that little else can. It speaks to people in a language they understand". The present paper will discuss how games have the power unite people from different origins, histories, cultures and beliefs as proposed by Mandela. However, other examples will also discuss that games may have the power to promote hate, segregation and violence among people that may even have the same nationality and culture. As a result, the current paper provides a reflection about games' 'power' over its players (or whomever is involved) and how they can bring out the best and the worst in them.

The paper is presented in three sections. First, in order to understand what creates such a unique environment that surround games, the 
complexity of games' nature is briefly introduced. Games are stated as a maturational function; as a cultural construction; and even as a spiritual element. Second, the paper discusses "what can games do", that is, historical events and academic references show how games have been used in the past to promote both good and bad events. The final section includes vignettes of two life experiences referencing similar games in order to illustrate how games can provide opposite outcomes regardless of cultural differences.

\section{What is the essence of games?}

Man is the only animal to present an 'incomplete gestation'; that is, he does not have the same motor and cognitive development as other mammals when born. Therefore, it has been suggested that games have a role in human development as they provide social interactions that compensates for man's lack of maturity (BRUHNS, 1999). Piaget (1986) has written significantly on how a child is led to exploratory games that are essential in providing opportunities for motor learning and discoveries. Within social relationships and playing activities, rituals, habits, education and culture are constructed, playing a significant role on man's maturity (GEERTZ, 1989). Therefore, would the 'maturational' essence of games be the reason for leading men to such fascination?

As a cultural construction, games have been attributed with complex meanings. In the ancient era, Greeks and Romans attributed religion and artistic values to their playing activities, considering it as sacred as a ritual (BROUGĖRE, 1998). This relationship between games and the formation of culture contributed to the creation of people's identity as part of the same community (HUIZINGA, 2005). Although there are considerable differences with how games are seen today, a game can still be compared to a ritual (even one that is sacred) in many different occasions. An illustration of this is evident by the great number of organizations that dedicate their full attention to organize and promote games. The International Olympic Committee (IOC) and FIFA are the largest examples of the category, each of them with over 200 nations affiliated, even more than the United Nations (UN) with only 192 nations. Therefore, would the 'cultural' essence of games be the reason for leading men to such fascination? 
Although games would not be needed by other animals due to their more advanced development at birth, or due to the fact that they cannot create 'bigger' meaning, there is still evidence of play in nonhumans. Piaget (1986) studied how chimpanzees would play different kind of 'make believe' games, and Huizinga (2005) also suggested that animals play when reporting his observations of puppies. So how can we explain the purpose of games for animals? On one hand, if animals as irrational creatures are able to play, they must be more than mechanical living things that may be driven by blind forces that would encourage them to play. On the other hand, if men play and they know that they are playing, they must be more than rational beings, given the assertion that play is irrational (HUIZINGA, 2005). So, would games have a 'spiritual' essence that would lead to its fascination regardless of any logical reasons?

Games can be seen as a natural instinct, as a cultural construction or even as a spiritual element, and most likely it can be an integration of all three elements. Their full comprehension is beyond our current understanding, and for this reason, there has not been a consensus over games' essence (ANDRÉ, 2009).

\section{What can games do?}

Since the Chinese communist revolution in 1949, no American citizen was allowed to enter China, causing a relationship rupture between the two countries. The turning point came in 1971with an international table tennis tournament, when the Chinese government invited the US team to play in their territory. The event, which allowed the first American group into the country for over twenty years, was subsequently known as "ping pong diplomacy", and it was considered primordial for making it possible for Richard Nixon, the United States president, to visit China one year later (WESTCOTT, 2010). Hong and Sun (2000) compared a table tennis ball to a small butterfly, while using a metaphor to illustrate how the 'ping pong diplomacy' had a butterfly effect to change the relationship of two countries.

In 2005, the UN declared the International Year of Sport and Physical Education (IYSPE). This significant support can symbolize how one of the most important international organizations has recognized the powerful tool that games can have to promote countries' development in many different areas. The IYSPE report recognized five dif- 
ferent areas to be addressed within sport and physical education: sport and education, sport and health, sport and development, sport and peace, and the benefits of "sports for all" (UNITED NATIONS, 2010). Each category has been focused for years in different research. Physical education models and curricula have been presented in order to address these issues since the 1970's.

The first approach that related physical education and life skills development was presented by Hellison (1973) and it was entitled as Humanistic Physical Education. According to the author, "humanism means a concern for man above all else behaviorally and a concern for man's social and emotional well-being" (HELLISON, 1973, p. 3). From 1973 until the present moment, Hellison and many other scholars have been working on the development of the model and its effectiveness (HELLISON; WALSH, 2002). Initially, Humanistic Physical Education presented seven goals to achieve: personality development; release of tension and aggression; value transfer (transferring learning to other environments); leadership; social mobility; sociometric (bringing people together) and self-actualization. Some of these goals were deeply considered on the subsequent studies of the model, others were not given further attention; nevertheless they were still focused in other approaches that emerged to discuss life skills development.

In the 1980's Teaching Games for Understanding (TGfU) was presented with a student-centered paradigm. The model suggested that games could be modified in order to give students the opportunity to fulfill their developmental needs (BUNKER; THORPE; ALMOND, 1986). At its roots, TGfU has been proposed to not only develop students' motor skills, as expected in most physical education programs, but also improve relationships among players and metacognitive skills such as, problem solving, and creativity (MANDIGO; CORLETT; ANDERSON, 2008). More recently, Butler (2006) proposed the usefulness of TGfU as an effective form to introduce value orientations such as democracy and inclusion, once the learners are able to appreciate the responsibility to protect individual and collective opinions as they discuss the games' modifications. Mandigo, Corlett and Anderson (2008) also present a few examples in which TGfU is used throughout different countries to facilitate life skills development such as respect and tolerance which in turn can promote a more peaceful and cooperative society. 
Sport Education was another model created to promote a more holistic learning of sport in physical education classes. In Sport Education, students would have to deal with diverse roles, such as refereeing, keeping score, compiling statistics, publicizing team performance, coaching, managing, and of course, performing. While being involved with multiple roles, students would obtain broader learning and would also be encouraged to affiliate to a group that worked together (same teammates) towards a common goal (SIEDENTOP; HASTIE; VAN DER MARS, 2004). According to the authors, the model promoted the improvement of motivation, inclusion, fair play and leadership.

Significant historical events like the 'ping pong diplomacy' and a few examples on how physical education models like the TPSR, TGfU and Sport Education could have been inspired to present the usefulness of games towards the same goals: promote a healthier and more peaceful environment that may provide life skills development. Nevertheless, can games also encourage negative outcomes?

In 2007, Iraq was the unexpected champion of the Asian Soccer Cup providing a rare moment of national joy in a country that has been facing political and war problems over the past decades. The excitement was even able to unite religion rivals to celebrate the national team accomplishment. Less than two years later, in 2009 in the city of Hilla (100km from Bagdad), the same sport was also responsible for a tragedy in the country. During a match between the two local professional teams, a player was shot by a fan when he was found in a scoring situation that would tie the match in the closing moments (TERRA, 2009). A superficial interpretation may suggest that the incident is an isolated case of violence that represents the many years of war in which this country has lived. Nevertheless, this is not a remote case in games and it is definitely not only associated to countries that are involved in wars. Negative outcomes can also be originated from playing games of diverse levels and in many different places.

In England, where a well social-economically developed population is established, there is one of the most famous groups that promote violence in professional soccer matches (The Hooligans). Lewis (1996) analyzed the hooliganism prior to World War One with a sociological perspective searching for a historical understanding of such phenomenon. The author could not find a connection between the violent actions presented by this group in modern times and the behavior presented by soccer fans of that period. Even though the population 
from the 1910's lived a much more disturbing moment, they would still limit their 'bad-cheering' with isolated swearing.

In North America, the National Hockey League (NHL) also presents scenes of violence in almost every game. Kerr (2006) analyzed the sanctioned and unsanctioned violence that frequently occurs in the league among 'fist-fights' that are considered part of the game by players, coaches and officials. From a competitive sport analysis, the fights could be considered as a strategy to win the game. Nevertheless, Engelhardt (1995) when analyzing the relationship between fights and final standings, found a negative correlation between these two elements; that is, teams that fought the most were also the ones with the worth rank position.

Although it would be desirable that physical education would be only known by promoting a reflexive player and sport viewer, physical education has been commonly used as a form to reinforce bad values on how sports became popular in our society. According to Gems (1999) sports have been used in education within an ideological conquest of capitalism. That is, sport promotes competitiveness, aggressive behavior and individualism.

Physical education classes have been commonly used to reinforce students' possible segregations, emphasizing their differences rather than promoting a reflexive play that would promote an understanding about diverse values. The declining participation in physical activity among youth in US society may have part of its origin due to gender, race and social class differences, which have not been properly considered in the physical education curriculum. The current sport-based curriculum emphasizes competition which creates diverse expectations that can promote disagreement and highlight differences (AZZARITO; SOLMON, 2005).

Although several physical education models have been developed in order to search for an improvement on some of the issues that were introduced, some of those models have been struggling to focusing their efforts to promote life skills rather than just providing learning about physical activities or enhancing performance in games.

Even though TGfU has the potential to provide a humanistic philosophy that would help children to make better choices and become better people; major research have limited their focus on how to address TGfU to help students to become better players (MANDIGO; CORLETT; ANDERSON, 2008). Sport Education may also present 
similar problems while developing a curriculum that should develop life skills and inclusion. Depending on how the model is implemented, it may be very similar to the so called traditional physical education by being very competitive and focusing on the outcome (HUNTER, 2006).

For over a decade, the National Basketball Association (NBA) have used the catch phrase "I love this game" to promote the league. The slogan success drives attention towards what many scholars (BROUGÈRE, 1998; BRUHMS, 1999; FREIRE, 2005; HUIZINGA, 2005) have argued in different studies: the human being is passionate for games. The choice of which game and how it is played may vary as diverse cultures are analyzed but its passion seem to be part of all playing activities. However, does love only promote goodness? Within examples that were taken from historical events and academic research, it has been presented that games are not inherently good; even though it may provide trust, teamwork and caring, it may also provide rate, segregation and individualism.

\section{Who will your students be: Terry or Ben?}

Between the late 1970's and during the 1980's Canada experienced two opposite scenarios that would have a significant impact on its sports history. Terry Fox and Ben Johnson showed opposite outcomes that were led by the similar running games, from the same country and from the same time period. The purpose of presenting these two vignettes is to demonstrate how regardless of cultural differences fantastic and awful outcomes may have its origin in games.

\section{Terry Fox}

Terrance Stanley Fox (Terry Fox) was born in Winnipeg, Manitoba (Canada) in 1958. From a very young age, he always possessed a passion for sports of all kinds, and although he was never a big child, he was very much competitive. In high school, he started to practice cross country running when he was encouraged by his physical education teacher, Bob McGill. This activity would have a great significance later on his life (SCRIVENER, 1981). Terry's competitiveness would follow him in his kinesiology undergraduate career when he would also play basketball. However in 1977, he was diagnosed with 
osteosarcoma (a form of cancer) which would force him to have his right leg amputated five inches above his knee. From that moment on, his life would change significantly (TERRY FOX RUN, 2009).

Terry was very touched by the conditions of some cancer patients while he was in the hospital. It was there where he formulated a plan to create the biggest competition he had ever been on: the "Marathon of Hope'. This marathon consisted of running from the east coast of to the west coast Canada with the purpose of raising money for cancer research. After training for three years on how to run with a mechanical leg he would start his running, having the goal to raise one dollar from every Canadian (TROTIER, 2005).

Terry started running in April 12, 1980 at St. John's, Newfoundland, and he was forced to stop on September 1st in Thunder Bay, Ontario due to his cancer complications. He ran $42 \mathrm{~km}$ every day (the length of a marathon) for 143 days, completing $5,373 \mathrm{~km}$. In June of 1981 he passed away. Terry did not finish the 'Marathon of Hope' nor did he raise all the money he set his goal for while he was still running. His death was received with great sadness throughout the country but his legacy lives on with the annual Terry Fox run that would continue to raise money for cancer research. The Terry Fox Foundation have raised over 400 million dollars up to today, over ten times more than Terry had set in his primarily objective (TERRY FOX RUN, 2009).

\section{Ben Johnson}

Benjamin Sinclair Johnson (Ben Johnson) was born in Falmouth, Jamaica in 1961. At early age he would show his interests in athletics by competing in little races along the neighborhood. His races would even have a few bets on the side, showing to be highly competitive. Ben immigrated to Canada and lived in Toronto with his mother and siblings in 1976. At age of 14, he was quiet, shy, weighted 97 pounds and was part of the minority of immigrants. In 1980, he would become a Canadian citizen. At age of 15 he met Coach Charlie Francis and started training at the Scarborough Optimists Track and Field Club. In 1981, Ben had his first international success by winning the silver medal in the World Cup Finals in Zurich. In 1984, he won the bronze in $100 \mathrm{~m}$ sprinting at the Los Angeles Olympic Games. 
In 1988, Johnson participated in his second Olympic Games in Seoul. He broke the world record in the $100 \mathrm{~m}$ final with 9.79 seconds, winning the gold medal in one of the most prestigious races. However, 48 hours later the glory was overtaken by shame when the athlete's urine test proved positive for anabolic steroids. It was the greatest scandal of Olympic Games history. It was not the first time that Ben was caught for using illegal substances while competing but this occasion had much bigger repercussion. As he grew is his career, Johnson would even gain the nickname "Big Ben" as he was proudly being recognized as a Canadian that gave great joy for having such a significant outcome. A complete change of scenario would occur with his cheating actions, leading the Canadians to feel embarrassed for an unethical athlete that represented their country (CRONIN; MAYALL, 1998).

\section{Finish line: final considerations}

It is not the purpose of this study to crucify Ben and praise Terry, both judgments have been done by society in many different ways and it will not be reinforced here. Most importantly, the paper proposes to foster a reflection between their actions (judgments) and their running activities. Therefore, by acknowledging their similarities and differences, the final reflections show that even though their outcomes were opposite, their relationships with the game were not far apart.

Firstly, it must be clear that both actions (the Marathon of Hope and cheating on the Olympics) were well thought out. For Terry, it took three years of training before he could start running his marathon; and it took over 10 years of training before Ben got to his second Olympics. Therefore, these actions must have been planned, and they cannot be compared with any 'good' or 'bad' decision that players may have during a game, when they can be emotionally involved. Secondly, it is understood from their life experiences that despite the fact that they competed in different levels, they were both highly competitive. As presented in previous examples, competition is commonly seen as a problem to be dealt in physical education classes. Nevertheless, does competition only lead to bad actions? How can we lead competition towards perseverance rather than cheating? Unfortunately, we do not have the answer for these questions, but we do believe it should be part of a physical education class discussion. 
Therefore, how can we understand that a game can drive people to both selfish and selfless actions? They both trained the similar running games, in a close time period, and were inserted in the same culture. The answer for this question is possibly hidden in two other unknown stories: Bob McGill (Terry's physical education teacher) and Charlie Francis (Ben's Coach). How were their influences over these two personalities? How did Bob encourage Terry in a way to be competitive and at the same time be so selfless while promoting the 'Marathon of hope'? How was Charlie involved in Ben's unethical procedures? Charlie was a former Olympian himself, what was his relationship with competition? Unfortunately, we cannot answer any of these questions, but it is known that teachers and coaches are one of the top influential role models (HARRIS, 1999).

In the late 1930's DEWEY (1997) already argued about the importance of providing positive experiences to students in learning environments. The usefulness of the body within games establishes a very rich connection between what is experienced and what it is learned, providing an environment where feelings and thoughts are brought together. For this matter, the game becomes a very powerful tool in learning (but it does not mean that it will be a good learning!). In the 1970's, Freire (2000) discussed the importance of teaching significant contents to students, i.e., in order to provide meaningful learning to students, they ought to be involved with subjects that were part of their culture. Once again, games appear to be a perfect match for good pedagogical practice. Even though games have different meanings in each culture, they seem to be somehow part of every one of them.

The idea that games should be relevant content to teach had been widely asserted and studied across many different school disciplines. Nevertheless, what is being emphasized in this paper is that 'meaningful' learning is not the same as 'good' learning. Much can be learned from a game that is harmful. So, although a game can be a powerful force to unite countries, promote understanding, teamwork and communication, it can also be a powerful tool to segregate, to promote violence and selfishness. Within the game, a physical educator can encourage students to be more like Terry or Ben. Consequently, the learning should not be focused on the game itself but on what is beyond its playful activity. 


\section{ALÉM DO JOGO: ANALISANDO-SE A UTILIDADE DOS JOGOS PARA PROMOVER O DESENVOLVIMENTO SOCIAL}

\section{Resumo \\ O presente artigo apresenta uma reflexão sobre o "poder" dos jogos em promover "boas" e "más" aprendizagens. O estudo está organizado em três seções. Primeiro, a complexidade da natureza dos jogos é brevemente introduzida, a fim de propor- cionar uma compreensão do porquê dos jogos apresentarem tamanho 'poder'. Se- gundo, uma análise de acontecimentos históricos e referências acadêmicas mostraram como os jogos têm sido utilizados para promover eventos bons e ruins. Finalmente, duas experiências de vida são apresentadas para ilustrar como os jogos podem fornecer resultados opostos, independentemente das diferenças culturais. Assim, por meio de reflexões provocativas, educadores físicos são motivados a pensar o que pode ser ensinado em aula que vai "além" da aprendizagem do jogo em si. \\ Palavras-chave: Teoria do Jogo. Educação Física e Treinamento. Desenvolvimen- to da Comunidade. \\ MÁS ALLÁ DEL JUEGO: ANÁLISIS DE LA UTILIDAD DE LOS JUEGOS DE PROMOCIÓN DE HABILIDADES SOCIALES}

\section{Resumen}

El artículo ofrece una reflexión acerca del "poder" del juego en la promoción de "buenos" y "malos" aprendizajes. El estudio se organiza en tres secciones. Primero, se introduce la complejidad de la naturaleza de los juegos, desde sus diversas perspectivas, con objeto de que se comprendan las causas que motivan este 'poder' de los juegos. Segundo, se realiza un análisis de los acontecimientos históricos $\mathrm{y}$ académicos que muestran cómo los juegos han promovido buenos y malos comportamientos. Por último, se presentan dos experiencias de vida para ilustrar cómo los juegos pueden proporcionar resultados opuestos, independientemente de las diferencias culturales. Así, por medio de reflexiones guiadas, se anima a los educadores físicos a que piensen en su día a día para poder enseñar aquello que va "más allá" del aprendizaje del juego en sí.

Palabras clave: Teoría del Juego. Educación y Entrenamiento Físico. Desarrollo de la Comunidad.

\section{Referências}

ANDRÉ, M. H; Rubio, K. O jogo na escola: um retrato das aulas de Educação Física de uma 5a série. Motriz, Rio Claro, v. 15, n. 2, p. 284-296, 2009.

AZZARITO, L; SOLMON, M. A. A reconceptualization of physical education: the intersection of gender/race/social class. Sport, education and society, Londres, v. 10, n. 1, p. 25-47, 2005. 
BROUGÈRE, G. Jogo e educação. Porto Alegre, Artes Médicas, 1998.

BRUHNS, H. T. O corpo parceiro e o corpo adversário. Campinas, Papirus, 1999.

BUNKER, D; Thorpe, R. A model for the teaching of games in the secondary school. Bulletin of Physical Education, Londres, v. 18, n. 1, p. 5-8, 1982.

BUNKER, D; THORPE, R; ALMOND, L. Rethinking games teaching. Irthingborough, UK, Nene Litho, 1986.

BUTLER, J. I. Curriculum constructions of ability: Enhancing learning through teaching games for understanding (TGfU) as a curriculum model. Sport, education and society, Londres, v. 11 n. 3, p. 243-258, 2006.

CRONIN, M; MAYALL, D. Sporting nationalisms: identity, ethnicity, immigration and assimilation. Portland, EUA: F. Cass, 1998.

DEWEY, J. Experience and education. Nova Iorque: Simon \& Schuster, 1997.

ENGELHARDT, G. M. Fighting behavior and winning national hockey league games: a paradox. Perceptual and Motor Skills, Missoula, MT, EUA, v. 80, n. 2, p. 416-418, 1995.

FLINTOFF, A; SCRATON, S. Girls and physical education. In: KIRK, D; MACDONALD, D; O'SULLIVAN, M. (Orgs). The handbook of physical education, Londres: Sage Pubns, 2006. p. 767-787.

FIFA. Confederations. Suiça, 2012. Disponível em: http://www.fifa.com/aboutfifa/organisation/confederations/index.html. Acesso em: 15 maio 2011.

FREIRE, J. B. O jogo: entre o riso e o choro. Campinas: Autores Associados, 2005.

FREIRE, P. Pedagogia do oprimido. Rio de Janeiro: Paz e Terra, 2000. 
GEMS, G. R. Sports, war, and ideological imperialism. Peace Review, Londres, v. 11, n. 4, p. 573-578, 1999.

GEERTZ, C. A interpretação das culturas. Rio de Janeiro: LTC, 1989.

HARRIS, J. R. Diga-me com quem anda.... Rio de Janeiro: Objetiva, 1999.

HELLISON, D. R. Humanistic physical education. Englewood Cliffs, NJ, EUA, Prentice-Hall, 1973.

HELLISON, D. R; WALSH, D. Responsibility-based youth programs evaluations: investigating the investigations. Quest, Londres, v. 54, p. 292-307, 2002.

HONG, Z; SUN, Y. The butter y effect and the making of 'ping-pong diplomacy'. Journal of contemporary China, Londres, v. 9, n. 25, p. 429-448, 2000.

HUIZINGA, J. Homo ludens: o jogo como elemento da cultura. São Paulo: Perspectiva, 2005.

HUNTER, L. Research into the elementary physical education programs. In KIRK, D; MACDONALD, D; O'SULLIVAN, M. (Orgs). The handbook of physical education, Londres: Sage Pubns, 2006. p. 580-592.

KERR, J. H. Examining the Bertuzzi-Moore NHL ice hockey incident: crossing the line between sanctioned and unsanctioned violence in sport. Aggression and Violent Behavior, v. 11, n. 4, p. 313-322, 2006.

LEWIS, R. Football hooliganism in England before 1914: A critique of the dunning thesis. International journal of the history of sport, Londres, v. 13, n. 3, p. 310-339, 1996.

MANDIGO,J; CORLETT, J; ANDERSON, K. Understanding of what? TGfU's role in the development of physical literacy. Physical \& health education journal, Ottawa, v. 70, n. 3, 2008. 
MERKEL, U. The politics of sport diplomacy and reunification in divided korea: one nation, two countries and three flags. International review for the sociology of sport, Londres, v. 43, n. 3, p. 289-311, 2008.

PIAGET, J. Formação do símbolo na criança: imitação, jogo e sonho, imagem e representação. Rio de Janeiro, Zahar, 1986.

SCRIVENER, L. Terry Fox: his story. Toronto: McClelland and Stewart, 1981.

SIEDENTOP, D; HASTIE, P; VAN DER MARS, H. Complete guide to sport education. Champaign, IL: Human Kinetics, 2004.

TERRA. Torcedor iraquiano mata jogador com tiro na arquibancada. Disponível em: http://esportes.terra.com.br/interna/0,,OI3638211-EI1863,00-Torcedor+iraquiano+mata+jogador+com +tiro+da+arquibancada.html. Acesso em 2 abr. 2009.

TERY FOX RUN. About Terry. Canadá. Disponível em: http://www.terryfoxrun.org/. Acesso em: 19 maio 2009

TROTTIER, M. Terry Fox: a story of hope. Toronto: Scholastic Canada, 2005.

UNITED NATIONS. Final report: international year of sport and physical education. 2005. Disponível em: http://www.un.org/sport2005/a_year/IYSPE_Report_FINAL.pdf . Acesso em: 9 mar. 2010.

WESTCOTT, K. From ping pong to Pyonguang. Disponível em: http://news.bbc.co.uk/2/hi/americas/7255407.stm. Acesso em: 21 nov. 2010 .

Recebido em: 04/10/2012

Revisado em: 28/01/2013

Aprovado em: 05/03/2013

Endereço para correspondência

mauro.ha@gmail.com

Mauro Henrique André

Illinois State University

Pensar a Prática, Goiânia, v. 16, n. 4, p. 956-1270, out./dez. 2013 
DOI: $10.5216 /$ rpp.v16i4.20539

150-C McCormick Hall

Campus Box 5120

Pensar a Prática, Goiânia, v. 16, n. 4, p. 956-1270, out./dez. 2013 